inauguración del Seminario Internacional Fiestas y mecenazgo en las relaciones culturales del Mediterráneo en la Edad Moderna (20-22 de septiembre, 2012), que organizó en la UMA junto con Eduardo Asenjo y Belén Calderón, cuyas actas acaban de publicarse. Esta ha sido su última actividad universitaria, porque, lo sabemos, Charo se ha jubilado. El Diccionario de la Lengua Española define este término como "persona que ha dejado de trabajar». Sin embargo, para mujeres como ella se deberían barajar otros vocablos, porque su actividad profesional habrá cesado, pero no la investigadora; sigue asistiendo a jornadas y congresos, continúa "navegando" con entusiasmo entre documentos y libros en archivos y bibliotecas, nos sigue deleitando con sus conferencias y charlas, y prosigue incansable su labor en la Academia y en las múltiples comisiones a las que pertenece... y, por supuesto, seguirá acudiendo, con su habitual modestia, allí donde la llamen y sea necesaria.

\title{
Rosario Camacho y la arquitectura malagueña del XIX
}

Francisco García Gómez

Universidad de Málaga

Hay experiencias que, como alumno, nunca se olvidan, de igual modo que hay profesores que dejan una huella más profunda que otros. En mi caso, siempre recordaré aquel día de 1990 en que Rosario Camacho, en la asignatura Arte español de la Licenciatura de Geografía e Historia, nos llevó al grupo de cuarto curso de paseo por la Málaga del siglo XIX. Nunca hasta entonces ese importante pasado decimonónico de la ciudad se me había aparecido tan esclarecedor como cuando nos iba desentrañando casas, iglesias y edificios públicos con el conocimiento y la profundidad que siempre han caracterizado a la gran maestra del Departamento de Arte.

Si bien la principal especialidad de Rosario Camacho ha sido la arquitectura y la cultura del barroco en general, la versatilidad y la apertura de miras han sido dos de los rasgos definitorios de su labor investigadora. No hay más que ver esta sección del Boletín de Arte para darse cuenta de tal diversidad de intereses. $Y$ de entre estos temas "tangenciales" a los que siempre ha atendido más allá de lo barroco, se encuentran el urbanismo y la arquitectura de la Málaga del XIX. 
Rosario Camacho es uno de los historiadores del arte que, en la universidad española, mejor entiende la arquitectura en todas sus dimensiones: su espacialidad, sus estilos, su ornamentación, sus aspectos tectónicos, sus materiales, su proceso constructivo, su integración en el contexto urbano... En este sentido, es una auténtica mente privilegiada para el estudio de la arquitectura, con una capacidad de discernimiento de este lenguaje similar a la de los mejores arquitectos. $Y$, al mismo tiempo, es capaz de expresarse por escrito con claridad, por lo que sus publicaciones son siempre de gran utilidad, tanto para el especialista como para el neófito o el simple aficionado.

En el caso que nos ocupa, en los años ochenta dedicó una serie de artículos al estudio de las intervenciones urbanísticas tras las desamortizaciones en la Málaga deI XIX. No era la primera vez que se estudiaban, por supuesto, pero sí con tanta exhaustividad, fruto sobre todo de su labor de investigación en el Archivo Municipal. En concreto, se trata de «Desamortización y ciudad. Málaga. Transformaciones en el solar del convento de San Bernardo" (Baetica, n. ${ }^{\circ} 6$, 1983), "Desamortización y ciudad: Málaga. La obra de Gerónimo Cuervo" (Baetica, n. ${ }^{\circ} 7,1984$ ) y "Transformaciones urbanísticas en Málaga: el solar del convento de Dominicas del Arcángel San Miguel» (Jábega, n. ${ }^{\circ}$ 64, 1989). En el segundo de estos artículos hace una panorámica sobre la labor de Gerónimo Cuervo, el arquitecto que más nuevos edificios de viviendas proyectó sobre los solares de conventos desamortizados, con obras tan representativas como las Casas de Campos en la Plaza de la Merced. En las otras dos investigaciones aborda dos conventos concretos: mientras que en el de San Bernardo se construirían nuevas casas en la confluencia entre las calles Granada y Méndez Núñez, sobre el del Ángel surgiría un amplio muestrario estilístico en la calle Luis de Velázquez, una de las mejores de la ciudad desde el punto de vista de la arquitectura doméstica.

Estos artículos también sirvieron para revalorizar aún más la figura de un arquitecto tan destacado como Cuervo, el equivalente en el XIX a lo que a principios del XX sería Fernando Guerrero Strachan. Una época esta última deudora estilísticamente de la arquitectura del siglo anterior, y que también abordaría en un magnífico capítulo de síntesis coescrito con María Morente: «Málaga, del Eclecticismo al Movimiento Moderno", en BRAVO NIETO, Antonio (ed.), Arquitecturas y ciudades hispánicas de los siglos XIX y XX en torno al Mediterráneo Occidental, Centro Asociado a la UNED, Melilla, 2005.

$Y$ este interés por la arquitectura y el urbanismo del Ochocientos también se aprecia a la perfección en una obra de referencia, dirigida por ella, 
como la Guía Histórico-Artística de Málaga, que presta especial atención a una arquitectura que no siempre ha sido ni entendida ni valorada adecuadamente. El centro de Málaga no es una ciudad de monumentos medievales, renacentistas ni barrocos (aunque los tiene, y muy buenos), sino básicamente una ciudad decimonónica, por lo que es esa arquitectura la que mejor define su aspecto, tanto en planta como en alzado.

La labor en este campo no se ha limitado a sus escritos, ya que Rosario Camacho ha dirigido numerosas tesis sobre urbanismo y arquitectura del XIX, en especial de esta última, conce- diendo gran importancia al estudio por tipologías, sin duda una de las mejores formas de acercarse a la arquitectura.

En suma, como en tantas otras cosas, Rosario Camacho ha enseñado también a los malagueños a admirar uno de sus grandes valores patrimoniales: la ciudad que se modificó y se creó a lo largo del Ochocientos. Y al enseñarles a apreciarla y valorarla, también se ha encargado de despertar sus conciencias para protegerla. Porque Camacho es una de las principales defensoras de la conservación del patrimonio malagueño: muchos de sus edificios siguen en pie gracias a ella y a su incansable labor. 